\title{
Analysis of diagnostic-therapeutic results after the first year of life in children of hearing disturbance risk groups
}

\author{
Sebastian Kocoń, Agnieszka Wiatr, Paweł Stręk, Patryk Hartwich, Remigiusz Ziarno, Jacek Składzień, \\ Maciej Wiatr
}

Chair and Department of Otolaryngology, Jagiellonian University Medical College, Kraków; Head of Clinic: Prof. Jacek Składzień, MD, Ph.D.

Article history: Received: 07.05.2018 Accepted: 15.05.2018 Published:30.06.2018

ABSTRACT: Introduction: It is assumed that the critical period for diagnosis of hearing disorders is the baby's first three months of life and that appropriate course and implementation of treatment and/or rehabilitation should begin before a child is six months old. However various kinds of problems may occur during auditory screening of a child may exceed this interval.

Aim: The aim of this study was an evaluation of auditory screening results for children over 12 months old with congenital hearing loss.

Material and methods: Results from 250 children were analyzed retrospectively. The study group consisted of children between one and three months old observed between 2015-2016. For the purpose of this analysis we divided the patients into four groups:

- children with Down Syndrome

- children with nervous system disorders

- children with cleft palate or both cleft palate and lip

- and children with congenital CMV.

To discuss performed diagnostics and treatment two groups of children were esteblished:

- with implementation of appropriate course of treatment

- without instituted treatment.

Results: 250 children were examined in Level III NICUs in the years 2015-2016. The highest proportion of children with theimplementedcourseofproceedings,wasingroupswithchildrenwithcongenitalCMV( $71,1 \%)$.ThehighestproportionofchildrensubstitutedwithahearingprosthesiswasobservedinthegroupofchildrenwithDownSyndrome.Thelowestproportionofchildrenwiththe implemented course of proceedings, was in groups with children with cleft palate or both cleft palate and lip (41,6\%).

Conclusions:

- Early implementation of treatment and/or rehabilitation in children with hearing disorders is crucial to prevent depressionofspeechandpsychologicaldevelopment.Itisimportantinchildrenwithcleftpalateorbothcleftpalateandlipevenifsurgical correction is discussed.

- The highest proportion of children with the implemented course of proceedings, was in groups with children with congenital CMV. This children should be observed despite of right results of hearing tests.

- In children with nervous system disorders 1 year period of observation is too short to exclude problems with hearing. KEYWORDS: $\quad$ diagnostics of hearing impairement in children, hearing screening tests, risk factors of hearing impairmants in children 


\section{INTRODUCTION}

Correct functioning of hearing is key for proper development of a child. The development of diagnostic methods, commonly available screening tests, expansion of facilities that deal with early treatment and rehabilitation in children with hearing loss, are directions for action which guarantee proper control, early detection of irregularities and immediate implementation of accurate treatment in children with hypoacusis.

It is assumed, that the optimal period to perform auditory screening tests is the first three months of a child's life, and proper therapy and implementation of treatment and/or rehabilitation should commence before the sixth month of age. However, practice shows that during auditory diagnosis in children, there appear various kinds of problems that extend this process. This phenomenon is particularly apparent in children, in whom, due to a malformation or genetic disorder, or perhaps other burdens associated with health, growth of the child, unstable, varying results are obtained during subsequent auditory screening tests.

Also, the absence of patients in auditory tests for health or social reasons often delays quick implementation of necessary therapeutical actions in the youngest patients.

\section{AIM OF PAPER}

The aim of the paper is to analyze the effects of auditory screening tests obtained after the first year of age in children with congenital hearing loss.

\section{MATERIAL AND METHOD}

Among 2,114 patients who underwent screening in 2015-2016 in a third-degree referential center, who participated in the Newborn Hearing Screening Program at the Specialist Clinic for Diagnosing and Rehabilitating Children and Youth with Hearing Defects of the Polish Association for the Deaf in Krakow, results of 250 children were subject to retrospective analysis. The researched group comprised of children aged from one to three months.

The analysis included results of patients originating from a hearing loss risk group $[1,2,3,4,5,6,7,8,9]$. For the purpose of the analysis, created were four small groups of patients with difficulties in diagnostic practice that delay final diagnosis and implementation of proper treatment. Qualification of a patient to a given group was done on the basis of documentation received from the neonatal unit as well as a questionnaire filled out by a laryngologist during the patient's first visit in the facility.

Groups of children included in the study are:

- children with Down syndrome

- children with other diseases or nervous system disorders

- children with cleft palate or both cleft palate and lip

- children with congenital CMV

The initial auditory screening test was assumed to be the result of TEOAE screening tests performed in the neonatal unit in the analyzed groups (tab. 1).

Next, diagnostic results obtained during the first year of the child's life were analyzed. The following tests were considered: impedance audiometry, TEOAE and ABR using snap-type stimuli.

The first year of a child's life was divided into four diagnostic periods, that is, 1-3 months, 4-6 months, 7-9 months and 1012 months. The intervals were marked as the I, II, III and IV diagnostic period, respectively.

For the purpose of analysis of diagnostic and treatment effects after the child's first year of life in the chosen risks groups with congenital hearing loss, two categories of treatment undertaken were indicated:

\section{IMPLEMENTED TREATMENT}

- INSERTION OF PROSTHESIS - the patients had unilateral or bilateral prosthesis insertion done into the hearing organ using hearing aid or cochlear implant

- OBSERVATION - the patient's hearing was recognized as correct, however, due to belonging to the risk group with a hearing loss risk factor, periodic audiological control is performed in a further period of life.

\section{LACK OF FINAL TREATMENT}

- The patient is still diagnosed and/or treated laryngologically

- Due to other health factors, implementation of diagnostic tasks is impossible

- Due to fluctuation of hearing level and/or lack of tolerance by the patient of the suggested treatment (e.g., reluctance towards wearing hearing aids), lack of final treatment.

For elaboration of data, statistical methods were used. The na- 


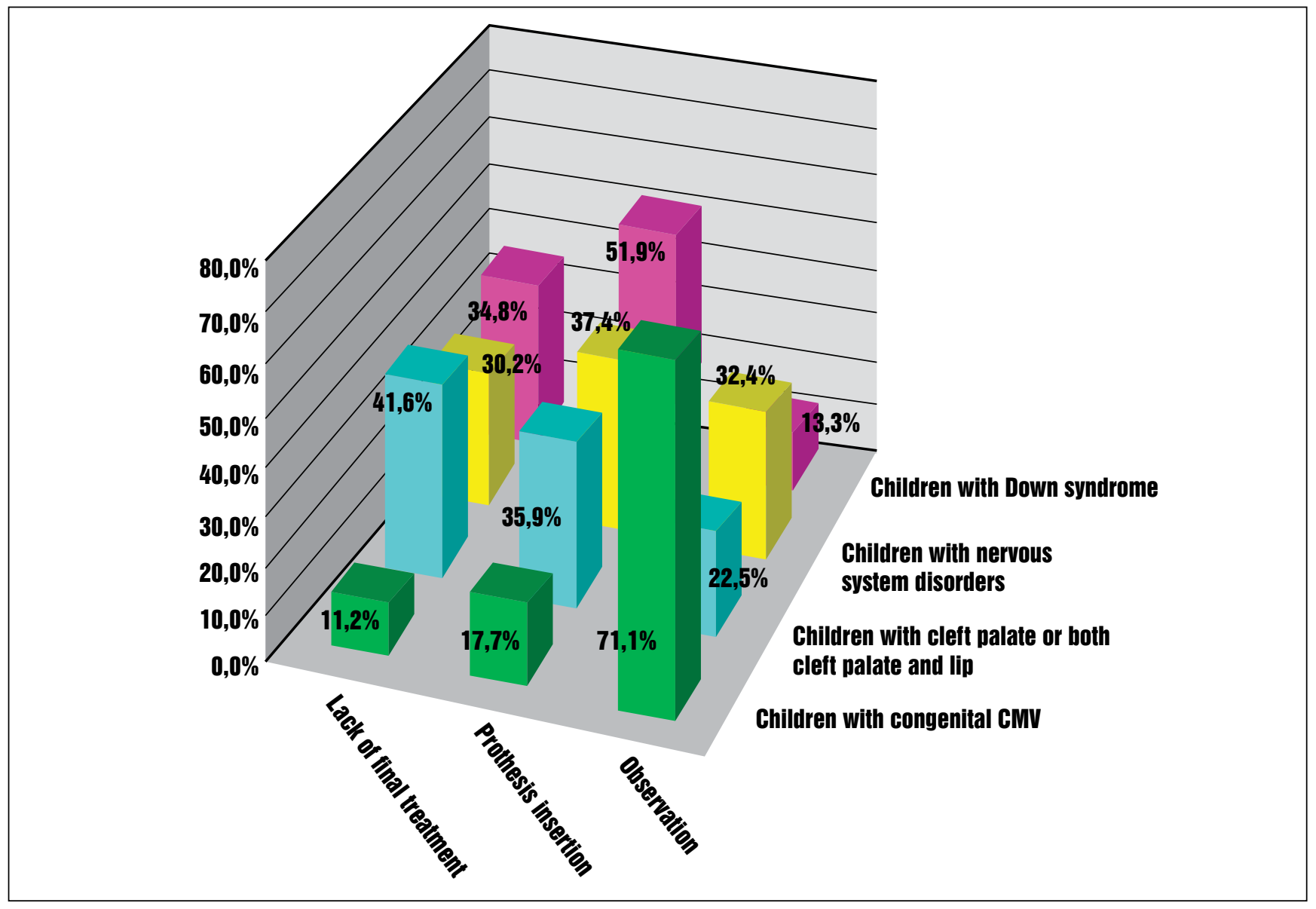

Fig. 1. Analysis of treatment following the first year of diagnostics in children from hearing disturbance risk groups.

ture of data allowed use of Fisher's exact test and NIR in the work (the smallest significant differences). Pearson's $\chi^{2}$-test was also used to analyze nonparamtric data. Taking into account the nature of results in the diagnostic tests, descriptive statistics, i.e., percentage presentation of results obtained was used to elaborate data.

\section{RESULTS:}

Fig. 1. and Tab. 2. present an analysis of treatment following the first year of diagnostics in children from selected risk groups with congenital hearing loss. The greatest number of patients from the observation category was noted in the group of children with congenital cytomegalovirus $-71.1 \%$. Children with other diseases or nervous system disorders made up a total of $32.4 \%$ cases. In children with cleft palate or both cleft palate and lip, this percentage was $22.5 \%$, the smallest share of patients in this category was observed in the group of children with Down syndrome $13.3 \%$.
It was observed, that the greatest share of children who had a prosthesis inserted into the auditory system were children with Down syndrome. On the other hand, in children with other diseases or nervous system disorders and children with cleft palate or both cleft palate and lip, there was a similar share of patients with a prosthesis, $37.4 \%$ and $35.9 \%$, respectively. Children with congenital CMV were inserted a prosthesis in $17.7 \%$ cases.

Lack of final treatment was observed in children with cleft palate or both cleft palate and lip in $41.6 \%$. An approximated share of this category was observed in children with Down syndrome $-34.8 \%$ and children with other diseases or nervous system disorders $-30.2 \%$. The smallest group comprised of children with congenital CMV - $11.2 \%$.

Fig. 2 presented results of statistical analysis (for $\chi^{2}=13.81$; $\alpha=0.05$ ) and diagnostic effects obtained during the first year of children's life from chosen risk groups with congenital hearing loss. It was observed that for all chosen groups subject to ana- 
Tab. I. Result of TEOAE screening test carried out in the neonatal unit in children subject to analysis.

\begin{tabular}{|c|c|c|c|c|}
\hline & $\begin{array}{l}\text { CHILDREN WITH DOWN } \\
\text { SYNDROME }\end{array}$ & $\begin{array}{l}\text { CHILDREN WITH OTHER DISEASES } \\
\text { OR NERVOUS SYSTEM DISORDERS }\end{array}$ & $\begin{array}{l}\text { CHILDREN WITH CLEFT PALATE } \\
\text { OR BOTH CLEFT PALATE AND LIP }\end{array}$ & $\begin{array}{l}\text { CHILDREN WITH CONGENITAL } \\
\text { CMV }\end{array}$ \\
\hline $\begin{array}{l}\text { Number and percentage } \\
\text { subject to analysis } \\
250(100 \%)\end{array}$ & $12(66,7 \%)$ & $66(26,4 \%)$ & $54(21,6 \%)$ & $68(27,2 \%)$ \\
\hline $\begin{array}{l}\text { Number and percentage of children } \\
\text { with abnormal (positive) result of } \\
\text { TEOAE screening performed in the } \\
\text { neonatal unit }\end{array}$ & $\begin{array}{l}58 / 62 \\
93,5 \%\end{array}$ & $\begin{array}{l}58 / 66 \\
87,5 \%\end{array}$ & $\begin{array}{l}35 / 54 \\
64,8 \%\end{array}$ & $\begin{array}{l}27 / 68 \\
39,4 \%\end{array}$ \\
\hline
\end{tabular}

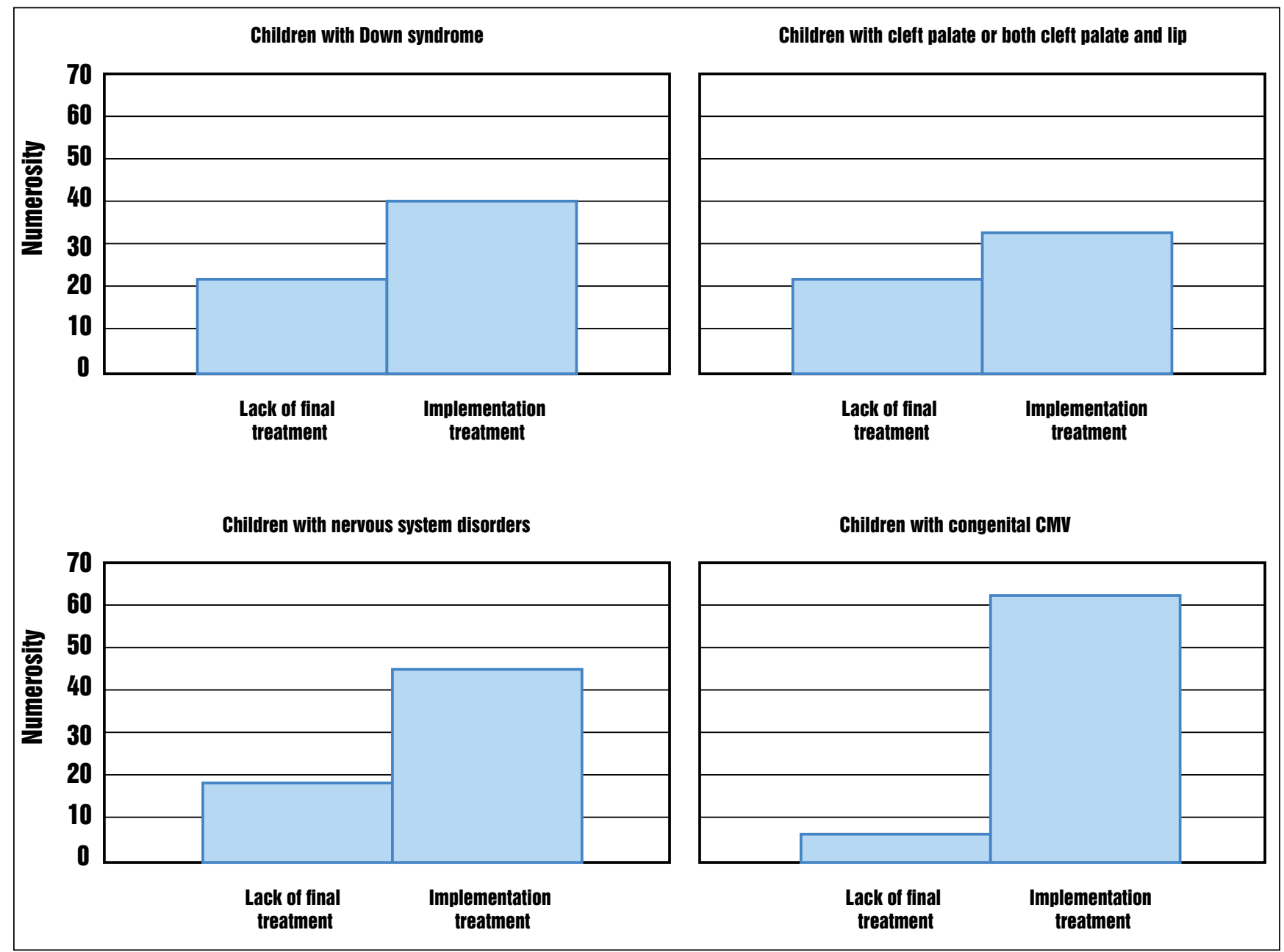

Fig. 2. Statistical analysis of effects of diagnostic procedures in children from hearing disturbance risk groups following the first year of diagnosis.

lysis, there were more patients with implemented treatment.

Fig. 3 presents results of statistical analysis (for $\chi^{2}=13.81 ; \alpha=0.05$ ) and diagnostic effects obtained during the first year of children's life from chosen risk groups with congenital hearing loss. It was concluded that there were the most patients with implemented treatment in children with congenital CMV - 33.9\%, and the least children with cleft palate or both cleft palate and lip - $18.6 \%$. In children with other diseases or nervous system disorders, there were $22,6 \%$ and in children with Down syndrome - $24,9 \%$. 
Tab. II. Analysis of treatment following the first year of diagnostics in children from hearing disturbance risk groups

\begin{tabular}{lcc}
\hline GROUP & $\begin{array}{c}\text { LACK OF FINAL } \\
\text { TREATMENT }\end{array}$ & $\begin{array}{c}\text { IMPLEMENTED TREATMENT } \\
\text { PROSTHESIS INSERTION } \\
\text { OBSERVATION }\end{array}$ \\
\hline Children with Down syndrome & $34,8 \%$ & $37,4 \%$ \\
\hline Children with other diseases or other damage of the nervous system & $30,2 \%$ & $35,9 \%$ \\
\hline Children with cleft palate or cleft lip and palate & $41,6 \%$ & $32,4 \%$ \\
\hline Children with cytomegalovirus (inherited) & $11,2 \%$ & $17,7 \%$ \\
\hline
\end{tabular}

\section{ANALYSIS OF RESEARCH RESULTS AND DISCUSSION}

Since the beginning of PPPBSN, procedures and rules for diagnostic management have been constantly perfected. Several dozen years of experience in the field of audiological diagnostics of young children resulted in the setting of certain standards of conduct as well as diagnostic and therapeutic procedures. However, everyday practice shows that there are situations in which the child's follow-up examination is justified in relation to particular groups of illnesses as well as due to the specifics of performed tests.

An optimal period for diagnosing hearing disorders is the first three months of a child's life, and appropriate therapeutic procedures, including rehabilitation, should start before the age of six months $[11,12,13]$. In recent years, along with dissemination of objective methods, the age of diagnosed children has decreased significantly to the first month. However, in practice, there appear various obstacles against prolongation of this period during diagnosis.

The study analyzed the diagnostic effects after the first year of the child's life, and in particular the assessment of actions undertaken in connection with the child's hearing after passage of this time (Tab.1, Fig. 1).

The group of patients in whom the procedure was implemented constituted the sum of children from the observation and prosthesis category $-70.5 \%$ of patients.

In the PROSTHESIS INSERTION subcategory - the greatest number of patients were children with Down's syndrome. As the analysis has demonstrated, due to chronic conductive hearing loss and frequent cases of mixed hearing loss, prosthesis insertion was required in $51.9 \%$ of patients. In the case of children with cleft palate or both cleft palate and lip, despite the possibility of improved hearing quality following cleft palate surgery, it was decided to insert a prothesis into the hearing

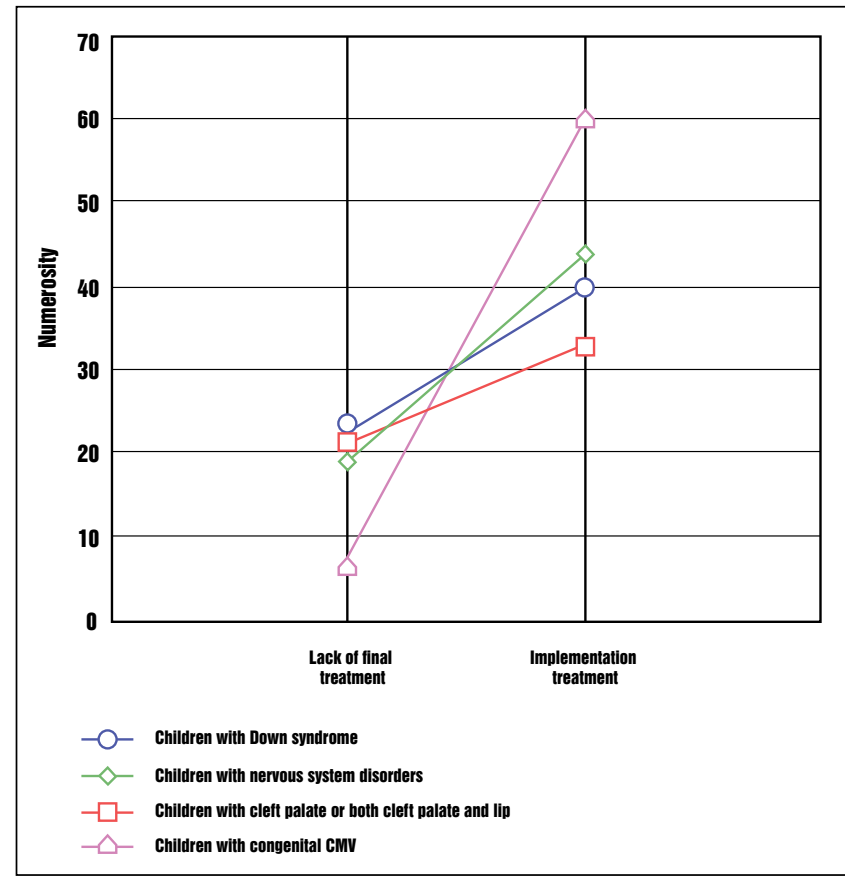

Fig.3. Statistical analysis of effects of diagnostic procedures in children from hearing disturbance risk groups following the firstyear of diagnosis.

organ in $35.9 \%$ cases. The risk of speech arrest, as well as risk of arrest of the child's psychological development in the longer term did not allow us to refrain from making that decision.

A smaller percentage of patients in this category (37.4\%) was observed in the group of children with other diseases or nervous system disorders. If the child was found to have hearing loss, it was most often of receptive nature, which prompted the use of hearing prostheses.

The least number of patients from the "prosthesis insertion" category was observed among children with congenital CMV (17.7\%).

As for the OBSERVATION subcategory - the highest percenta- 
ge were children with inherited cytomegalovirus (71.1\%). This results from the fact that up to the first year of life, no hearing loss was observed in many children. This result is confirmed by numerous reports. However, the chronic effect of CMV on the child's hearing induces periodic auditory screening tests even in the case when results indicate normal hearing $[14,15$, $16,17,18,19]$.

In the group of children with other diseases or nervous system disorders, $32.4 \%$ were subjected to observation. This group was monitored due to risk of hearing loss, despite the previously correct results of objective auditory screening tests. There was a concern, that due to neurological burdens, a period of one year would be too short to definitely exclude the appearance of hearing problems.

For the group of children with cleft palate or both cleft palate and lip, despite correct auditory screening results, out of concern that hearing deterioration may occur after the analysis period, $22.5 \%$ of patients were included in the "observation" group. For the same reason, the percentage of children with Down syndrome was $13.3 \%$.

The greatest percentage of patients in the "lack of final treatment" category were children with cleft palate or both cleft palate and lip - 41.6\%. Due to the fact that until their first year of life, in most cases these children did not finish treatment associated cleft palate or cleft lip and palate reconstructive surgery, the results of auditory tests had a fluctuating nature, preventing implementation of final treatment. It sometimes happens that these children, after "premature" insertion of prosthesis with hearing aids do not approve of these devices. This is probably due to a "non-stabilized" hearing level associated with periodically occurring conductive hearing loss component.

A smaller group in this category were children with Down syndrome and children with other diseases or nervous system disorders (34.8\% and $30.2 \%$, respectively).

In the case of children with Down syndrome, the emerging conductive hearing loss component and variations in the values of test results do not guarantee that the implemented treatment will be adequate. This can be manifested, for example, by reluctance to wear hearing aids.
In the group of children with other diseases or nervous system disorders, the frequently anomalies in results obtained or a common lack of correlation between the child's subjective reaction to auditory stimuli, and results of objective auditory tests cause [18], that in the period from the first year of the child's life, often other proper individual treatment is implemented, such as performance of additional tests which allow to expand knowledge on the child's health condition (computed tomography, magnetic resonance, EEG of the brain), the child is referred to other specialists, e.g., neurologist, pediatrician, psychologist.

The smallest percentage of patients included in this category were children with congenital CMV $11.2 \%$. In this group, results of objective auditory tests are most often unambiguous and allow the person managing the child's treatment to make appropriate decisions. The percentage of children in this group was composed of cases of unilateral mild hearing loss that did not exceed $35 \mathrm{~dB}$ nHL. This level of hearing loss did not require prosthesis and in this case, the child was subjected to periodic logopedical and psychological consultations to observe development of speech as well as mental development.

\section{CONCLUSIONS}

The analysis of final diagnostic effects obtained during the course of the first year of life in children with congenital hearing loss from the chosen groups showed that:

- The risk of speech arrest, as well as risk of arrest of psychological development of the child in the longer term did not allow us to refrain from making that decision. This also applies to children with cleft palate or both cleft palate and lip despite planned surgical procedures of the palate.

- The highest percentage of children with implemented treatment was observed in the group with congenital CMV. Chronic influence of CMV virus on children's hearing inclines towards performance of periodic auditory screening tests even when the results indicate normal hearing.

- In children with neurological abnormalities, the followup period during the first year of the child's life is often too short for definite exclusion of hearing problems.

\section{REFERENCES}

1. Beswick R., Driscoll C., Kei J. et al.: Which risk factors predict postnatal hearing loss in children? J. Am. Acad. Audiol. 2013 ; 24 (3): $205-213$.

2. $\quad$ Beswick R., Driscoll C., Kei J.: Monitoring for postnatal hearing loss using risk factors: a systematic literature review. Ear Hear. 2012 ; 33 (6): 745-756.

3. Dobrzańska A., Gołkowska M., Janowska J., Czech-Kowalska J., Pleskoczyńska A.: Kliniczne zastosowanie otoemisji akustycznych we wczesnej diagnostyce 
uszkodzenia słuchu u noworodków i niemowląt. Postępy Neonatologii. 2003; 1 (1): 71-79.

4. Kochanek K.: Otolaryngologia dziecięca. Łódź, 2007: 81-87.

5. Radziszewska-Konopka M.: Uszko - Biuletyn Programu Powszechnych Przesiewowych Badań Słuchu u Noworodków; $2005: 12$.

6. Wróbel M.: Czynniki ryzyka w analizie I poziomu referencyjności PPPBSuN, Podsumowanie działalności II i III poziomu referencyjności. Uszko - Biuletyn Programu Powszechnych Przesiewowych Badań Słuchu u Noworodków. 2011: 8-17.

7. Gryczyński M., Pajor A.: Audiologia Kliniczna Mediton (red. Śliwińska-Kowalska M.), Łódź 2005: 51-60.

8. Pucher B., Jończyk-Potoczna K., Jakubczyk-Szymańska K. et al.: Zdrowa mama, zdrowy noworodek - czynniki ryzyka uszkodzenia słuchu u niemowląt w materiale Kliniki Otolaryngologii Dziecięcej Uniwersytetu Medycznego im. K. Marcinkowskiego w Poznaniu. Nowiny Lekarskie. $2012 ; 81$ (4): $311-315$.

9. Wróbel M., Greczka G.: Analiza czynników ryzyka na I poziomie Programu Powszechnych Przesiewowych Badań Słuchu u Noworodków w Polsce. Uszko Biuletyn Programu Powszechnych Przesiewowych Badań Słuchu u Noworodków. 2011: 8-11.

10. Cutler J., Lenzi G., Berrettini S. et al.: How to motivate newborn hearing screening in the absence of a national programme: a collaboration between parents and professionals. J. Matern. Fetal. Neonatal. Med. 2012, 25, 4: 114-115.

11. Kochanek K.: Powszechne badania przesiewowe słuchu u noworodków. Magazyn Otolaryngologiczny. 2003 ; II (2): 50-51.

12. Kochanek K.: Otolaryngologia dziecięca. Łódź 2007, 81-87.

13. Barbi M., Binda S., Caroppa S. et al.: A wider role for congenital cytomegalovirus infection in sensorineural hearing loss. Pediatr. Infect. Dis. J. 2003 ; 22 (1): 39-42.

14. Dollard S.C., Grosse S.D., Ross D.S.: New estimates of the prevalence of neurological and sensory sequel and mortality associated with congenital cytomegalovirus infection. Rev. Med. Virol. 2007; 17 (5): 355-363.

15. Fowler K.B., Boppana S.B.: Congenital cytomegalovirus (CMV) infection and hearing deficit. J. Clin. Virol. $2006 ; 35$ (2): $226-231$.

16. Ogawa H., Suzutani T., Baba Y.: et al.: Etiology of severe sensorineural hearing loss in children: independent impact of congenital cytomegalovirus infection and GJB2 mutations. J. Infect. Dis. 2007; 195 (6): 782-788.

17. Woźniakowska-Gęsicka T., Wróblewska W., Wiśniewska-Ligier M.: Rola wirusa cytomegalii w patologii wieku rozwojowego. Ped. Pol. 2006 ; 81 (9): 674-678.

18. Ross S., Fowler K., Ashrith G., et al.: Hearing loss in children with congenital cytomegalovirus infection born to mothers with preexisting immunity. Pediatrics. 2006; 148 (3): 332-336.

19. Keith R.W.: Zaburzenia procesów przetwarzania słuchowego. W: Audiologia Kliniczna (red. Śliwińska-Kowalska M.). Wyd. I. Mediton, Łódź; 2005: 367-375.

Word count: 2120 Tables: 2 Figures: 3 References: 19

Access the article online: DOI: 10.5604/01.3001.0012.0479 Table of content: https://otolaryngologypl.com/issue/11199

Corresponding author: Maciej Wiatr; Chair and Department of Otolaryngology, Jagiellonian University Medical College, Krakow, Poland; e-mail: mwiatr@mp.pl

Copyright (c) 2018 Polish Society of Otorhinolaryngologists Head and Neck Surgeons. Published by Index Copernicus Sp. z o.o. All rights reserved.

Competing interests: The authors declare that they have no competing interests.

Cite this article as: Kocoń S., Wiatr A., Stręk P., Hartwich P., Ziarno R., Składzień ]., Wiatr W.; Analysis of diagnostic-therapeutic results after the first year of life in children of hearing disturbance risk groups; Otolaryngol Pol 2018; 72 (3): 11-18 
